\title{
The Effect of Artificial Intelligence (AI) on Firm Labor Structure
}

\author{
Mei Xue \\ Boston College \\ mei.xue@bc.edu
}

\author{
Xing Cao \\ Harbin Institute of Technology \\ xcao@hit.edu.cn
}

\author{
Xu Feng \\ Tianjin University \\ fengxu@tju.edu.cn
}

\author{
$\mathrm{Bin} \mathrm{Gu}$ \\ Boston University \\ bgu@bu.edu
}

\author{
Yongjie Zhang \\ Tianjin University \\ yjz@tju.edu.cn
}

\begin{abstract}
This paper aims to study the effect of AI on firm labor structure. Using a unique panel data of over 1300 publicly listed companies in China from 2007 to 2018, we study the effect of AI on firms' labor composition measured by labor force's education levels. We further compare the effect of AI on firms in the manufacturing sector to the effect on firms in the service sector. Our analysis generates two major findings. First, the use of AI leads to a larger labor demand increase for jobs requiring lower education levels than those requiring higher education levels. Second, the effect is stronger in the service sector than in the manufacturing sector. These findings contradict predictions of the "skillbiased technological change" (SJTB) and U-shaped "job polarization" effects proposed in the prior literature. We propose that "technology-enabled deskilling" effect is driving the effect of AI on labor structure.
\end{abstract}

\section{Introduction}

Artificial intelligence (AI) has become a driving force of many technology and business innovations in recent years. AI is believed to have multiple and often conflicting influence on labor forces. On the one hand, it can augment a worker's skills and hence improve the worker's productivity and thus increase labor demand. On the other hand, it can replace certain jobs traditionally carried by human workers through automation, including some white-collar jobs that traditionally require more sophisticated and advanced knowledge and skills, a distinction that separates AI from previous generations of automation technologies (e.g. IT-enabled manufacturing systems) that mostly affect simple and repetitive jobs. However, to the best of our knowledge, research that empirically analyzes the effects of $\mathrm{AI}$ on labor force structure at the firm level has been scarce [1][2].

In this study, we investigate the following research questions with an empirical study of a panel data set of over 1300 companies in China from 2007 to 2018: 1) How does AI affect the labor structure of a firm? 2) How does AI's effect on labor structure in the manufacturing industry differ from that in the service industry? As noted in Frank et al [3], "lack of empirically informed models of key microlevel processes (e.g., skill substitution and human-machine complementarity) and insufficient understanding of how cognitive technologies interact with broader economic dynamics and institutional mechanisms" are among "the barriers that inhibit scientists from measuring the effects of AI and automation on the future of work." By exploring the questions above, this study adds valuable understanding about the "microlevel processes" and the "institutional mechanisms" discussed herein.

\section{Literature Review}

Following the literature [4], we define AI as "intelligent (machine) agents, which are machines, software or algorithms that act intelligently by recognizing and responding to their environment." This definition highlights an important characteristic of AI its ability to recognize and respond to its environment. This ability allows AI to provide customized or individualized responses, while earlier generations of automation technologies are more known for automation of routinized responses and processes. The distinction of the two different automation technologies has great implications for their impact on labor demands.

Several theories and models had been proposed to explain the impact of automation technologies on labor demand, with the following two theories arguably discussed the most: the skill-biased technological change (SBTC) and the task-based framework.

\subsection{The Skill-biased Technological Change}

The Skill-biased Technological Change (SBTC) was developed based on the finding of a strong correlation between the adoption of automation technologies and the increased use of better educated (e.g. college-educated) labor since the late 1970s [5][6][7]. According to this theory, labor forces can be divided into two groups based on their skills and how automation technologies enhance the capability or efficiency of human labor. One important hypothesis is 
that technology change is "skill-biased" [8]. That is, the complementary effect technology advancement is stronger for jobs requiring higher skills. Thus, the gain in productivity of high-skilled and better-educated workers due to technology advancement will be larger than that of the low-skilled and less educated workers. As a result, technological advancements drive employers to hire more high-skilled and better-educated workers and fewer low-skilled and less-educated workers [9]. This period witnessed a demand surge for high-skilled IT workers and a supply shortage of such workers due to the burst of newly created IT related job positions [8].

\subsection{Task-based Framework (Job Polarization)}

However, later studies found evidence of a Ushaped job polarization effect in the employment trends from the 1980 s to 1990 s in the U.S, the United Kingdom, and Europe [10][11][12]. The term "job polarization" refers to the finding of growth in employment in both the highest-skilled and paid (professional and managerial) and lowest-skilled (personal services) and paid occupations, with declining employment in the middle of the distribution (manufacturing and routine office jobs typically).

"Skill-biased" framework could not be used to explain this phenomenon effectively. Thus, some researchers extended the framework of "skill-biased" theory and proposed a task-based framework for explanation [13][14]. This stream of research suggests that IT and other automation technologies is not suitable to take on non-routine cognitive tasks that requires context-specific analysis, in-person communications or creativity. The workers that are the most suitable to take on these jobs are typically those with higher education and analytical skills. Meanwhile, IT and other automation technologies are also not suitable to take on the non-routine manual tasks, such as cleaning and personal health care. Meanwhile, the strong positive impact on overall productivity of IT and other automation technologies led to an explosive growth of businesses, which in turn lead to more demand for labors for non-routine cognitive tasks and non-routine manual tasks, thus the U-shape polarization effect.

\section{Hypothesis Development}

\subsection{AI and Labor Structure}

With the observation of overall job increases in the past two decades, and the advances of new automation technologies such as AI and robotics, some researchers have started to question whether job polarization, that has been found widely exist from the 1980s to 1990s in the developed countries, will persist [15][16][17]. For the period 2000-2007, Autor [18] and Acemoglu and Autor [19] show that the share of low-skilled jobs increased rapidly while the shares of high-skilled or middle-skilled jobs did not. This is in contrary to the predictions of both the SBTC theory and the "Job Polarization" theory.

In this study, we argue that the effect of AI on labor structure can be explained by neither the SBTC theory nor the "Job Polarization" theory. Rather, AI leads to technology-enabled deskilling, which benefits disproportionally the low-skilled labor force. Technology-enabled deskilling was first noted in the early days of the industrial revolution. Reviewing the history of industrialization makes it clear that technology advances released a strong demand for lowskilled workers. In the textile industry, low-skilled sewing machine operators took the jobs of the highskilled loom workers [20]. In the shipping industry, because of the adoption of the steam engines, middleskilled professional sailors were replaced by the lowskilled engine operators [21]. In the manufacturing industry, with the prevalence of assembly lines, lowskilled assembly line workers replaced the craftsmen who possess more comprehensive set of skills [22]. Technology-enabled deskilling argues that, by taking over the part of a job that requires more skills and education, automation technologies can lower the skill thresholds of workforce for the job, since the rest of the job can now be completed by workers with less skills and education.

The surge of high demand for low-skill jobs has emerged again in the era of AI, as it did in the era of industrialization. For example, it used to be that a taxi driver had to master a complex set of knowledge about the streets and locations of a city in order to perform well in his job. Today, map and navigation applications have made it a job essentially that could be handled by anyone who knows how to drive. As a result, the high skill requirement of the job has been reduced to a low skill level. We therefore propose:

H1: AI has a stronger positive impact on the demand for low-skill labors than the demand for highskilled labors.

\subsection{Manufacturing versus Service Industries}

Acemoglu and Restrepo [4] argues that AI is an "intelligent replacement" technology that can operate by recognizing and responding to its environment automatically. This feature makes AI capable of dealing with non-routine jobs. Non-routine jobs are particularly prevalent in the service industry, as all services require interactions between a service provider and a customer 
and the ability to responding to a customer's individual needs is critical. As AI enables such individualized response, it reduces the skill requirement for service workers. Such reduction in skill requirement could lead to a significant increase in labor supply due to the high elasticity of labor supply at the lower end [30]. Bryjolfsson et al. [31] conducted a detailed analysis on "suitability for machine learning" (SML) of 18,156 tasks, and 964 occupations in the O*NET database. Four out of the top five high SML occupations are in the service industries. We thus expect the phenomenon of "technology-enabled-deskilling" associated with AI to affect service industries more than manufacturing industries.

H2: AI has a stronger positive impact on the demand for low-skill labors in service sector than in the manufacturing sector.

\section{Data and Analysis}

\subsection{Data and Measurement}

Our empirical analysis uses a panel data set of 1387 publicly listed firms in China from 2007 to 2018, a total of 12 years. Our original sample has all the 3597 companies publicly traded in the Chinese Share-A stock market and it has 24,265 observations for the time span. We then delete a firm if it meets one of the followings: 1) firms whose stock trading was halted for more than half of total trading days in a year; 2) firms with abnormal variations (more than 5 times of standard deviation); or 3) firms with missing data. The final sample we use for the study has 1387 companies and 4563 observations. The data set is assembled from several data sources.

Labor Structure: The impact of AI on labor demand varies by the required skill levels [16][19]. As education required for a job is highly related to the required information processing and analysis skills for the workers, we focus on the impact of automation technology on the education structure of the labor force. We obtain the educational levels of employees of each firm. We further classify them into three categories: Category 1 are employees with highest education at the $\mathrm{PhD}$ level. Category 2 are those with highest education at the bachelor's or master's level. Category 3 are those with highest education below the bachelor's level. We use the log count value of the three types of employees to capture the labor structure of the firm. The data comes from the RESSET database.

IT Deployment: For IT deployment, we use a company's annual IT expenditure/investment to

\footnotetext{
${ }^{1}$ See Appendix Table 1.
}

measure its deployment of IT, including investment and expenses in electronic devices, computers and their accessories. This measure is consistent with prior IS literatures that investigate the effect of IT on labor demand using IT investment or expenditure to measure IT inputs [23][24]. The data also comes from the RESSET database.

AI Deployment: For AI deployment, we use the proxy AI ratio identified using TALWEM from each firm's annual report as described below. Since AI application is still at its early stage, the type of data similar to what we use to measure IT deployment is not available for the firms in our sample. As a result, the AI deployment proxy derived from the firm's annual report is the only feasible option here. Our assumption is that the more AI related terms appear in a firm's annual report, the more AI is deployed by the firm [25]. For identification, we use a dictionary to count numbers of AI terms in the firms' annual reports. Unlike the previous practice of subjective choice of terms used in the dictionary, we use a machine learning method (Word Embedding) to create our AI dictionary. Word Embedding uses neural network to develop models used for text search and identification automatically and thus is considered as more objective and accurate [26][27]. In particular, we use a Chinese Word Embedding model developed by Tencent AI Lab. Tencent AI Lab Word Embedding Model (TALWEM) includes over 8 million Chinese words and idioms with 200 dimensions. The training data covers contents available on the Internet, news, novels and other text sources as well words and idioms used by Wikipedia and Baidu Baike. Song et al. [28] provides the details about the algorithm of the TALWEM. We use "artificial intelligence" in Chinese as the seed word for the TALWEM model to find all the words that have a correlation with the word "artificial intelligence" above 0.75 . A total of 45 such words ${ }^{1}$ were identified according to the model. We then calculate the AI deployment ratio using equation (1) below:

$$
\text { AIDptRatio }_{i, t}=
$$

$\frac{\text { The number of AI related terms in annual report }}{i, t}=1000-$ Industry_year_average $e_{A I, t}$

We also use TALWEM to find the ratio of IT terms in the firms' annual reports and use it as a control variable in the model.

$$
\text { ITDptRatio }{ }_{i, t}=
$$

The number of IT related terms in annual report ${ }_{i, t} \times 1000-$

The number of total words in annual report $t_{i, t}$

Industry_year_average $e_{I T, t}$

We start with the seed word "information system" in Chinese, using TALWEM we found 40 words $^{2}$ having a correlation with the word "information system"

\footnotetext{
${ }^{2}$ See Appendix Table 2.
} 
above 0.75 . We use these dictionaries to search the annual reports of the companies to calculate the proxies for IT deployment and AI deployment.

Control Variables: To control for local labor supply with complementary skills (Tambe's [24]), we include the number of local skilled workers measured by the annual number of college graduates in the province as a control variable in our empirical model. Other control variables including firm size, age, financial data including financial leverage and capital expenditure, and annual stock return for their potential influence on labor force structure of the firms. The number of annual undergraduate graduates comes from the National Bureau of Statistics of China, the financial data comes from the RESSET database and other data comes from the WIND database.

Table 1 below show the summary statistics of the variables used in our empirical model. (For variable definitions see Appendix Table 3) .

\section{Table 1. Summary Statistics}

\begin{tabular}{llllll}
\hline Variable & Obs & Mean & Std. Dev. & Min & Max \\
\hline Labor Structure & & & & & \\
\hline $\ln ($ PhD) & 4,195 & 0.40 & 0.97 & 0.00 & 6.46 \\
$\ln$ (BMDegrs) & 4,195 & 5.43 & 2.11 & 0.00 & 9.91 \\
$\ln$ (Others) & 4,195 & 7.18 & 1.42 & 0.00 & 11.22 \\
\hline AI Deployment \& IT Deployment & & & \\
\hline AIDptRatio & 4,194 & 0.01 & 0.25 & -0.63 & 2.29 \\
ln(ITUse) & 4,195 & 17.02 & 1.55 & 10.30 & 22.07 \\
\hline Control Variables & & & & & \\
\hline ITDptRatio & 4,194 & 0.00 & 0.07 & -0.22 & 0.62 \\
In(BAGrads) & 4,195 & 2.58 & 0.60 & -1.51 & 3.27 \\
$\ln$ (Assets) & 4,195 & 21.95 & 1.32 & 17.67 & 28.29 \\
$\ln$ (Age) & 4,195 & 8.70 & 0.34 & 7.11 & 9.93 \\
FinLev & 4,195 & 2.42 & 2.41 & 1.01 & 44.85 \\
$\ln$ (Capex) & 4,195 & 18.34 & 1.75 & 7.50 & 23.72 \\
Returns & 4,195 & 0.09 & 0.51 & -0.95 & 3.47 \\
\hline
\end{tabular}

\subsection{Empirical Strategy}

We match the firms in our sample using Propensity Score Matching (PSM). Using whether the company uses AI, company's total assets and industry as the matching criteria and its total number of employees as the dependent variable, with 1:4 ratio, we match the firms in the sample. We are able to match 1353 firms in our sample.

To estimate the effects of AI use and IT use on firm labor structure, we run a panel data regression model with time and firm fixed effects below:

Labor Structure $_{i, t(t+1)}=\alpha+$ $\beta_{1}$ AIDptRatio $_{i, t}++\beta_{2} \ln (\text { ITDpt })_{i, t}+$ $\beta_{3}$ ITDptRatio $_{i, t}+\xi_{\text {Firm }}+\eta_{\text {Year }}+\sum_{j} \gamma_{j}$ Control $_{i, t}+$ $\varepsilon_{i, t}$

To assess the differential effects of AI and IT use on firms in the manufacturing industries versus those in the service industries, we divide the sample into subsamples based on the firms' industry sectors, i.e. we divide all firms into the first, second and third sectors (agriculture, manufacturing and service sectors). As less than $2 \%$ of all public firms are in the agriculture sector, we remove them from the analysis. We run individual fixed effect panel data analyses of the subsamples based on equation (3) below.

$$
\text { Labor Structure }_{i, t(t+1)}=\alpha+
$$

$\beta_{1}$ AIDptRatio $_{i, t} \times \operatorname{IndMfg}_{i, t}+\beta_{2}$ AIDptRatio $_{i, t} \times$

$\operatorname{IndSvc_{i,t}}+\beta_{3} \ln (\text { ITDpt })_{i, t} \times \operatorname{IndMfg} g_{i, t}+$

$\beta_{4} \ln (I T D p t)_{i, t} \times \operatorname{IndSvc_{i,t}}+\beta_{5} \operatorname{IndMfg} g_{i, t}+$

$\beta_{6}$ IndSvc $_{i, t}+\beta_{7}$ ITDptRatio $_{i, t}+\xi_{\text {Firm }}+\eta_{\text {Year }}+$

$\sum_{j} \gamma_{j}$ Control $_{i, t}+\varepsilon_{i, t}$

\section{Results}

Table 2 shows the correlations among the variables. Note that correlation between AIDptRatio and $\ln$ (ITDpt) is relatively insignificant at only 0.05 .

Table 3 shows the results of regression analysis based on equation (2). Column 1, 3 and 5 indicate the impact of AI and IT deployment on the count of employees of different education levels at the firm at period T. Column 2, 4, and 6 show the results of the same analysis for period $\mathrm{T}+1$.

We first examine the impact of IT deployment. From Column 1,3, and 5, IT deployment is shown to have significant positive effects on the labor demands of employees across different education levels including those with highest education below the bachelor's, at bachelor's and master's, and at Ph.D.'s. The finding is consistent with the finding in Dixon, Hong and $\mathrm{Wu}$ [29] - the use of robots results in an overall increase of employment using a novel data of Canadian firms. It is also consistent with Autor [15][17] which finds overall growth of jobs in almost every sector of our economy following major technology innovations after a period of time.

We next focus on the impact of AI deployment on labor structure. The results in Table 3 show that AI deployment has a significant positive effect on the firm's labor demand for employees with highest education level below the bachelor's, but a negative, albeit insignificant, effect for employees with highest education level above the bachelor's.

To compare the effects of AI deployment on the labor demand for different education levels, we conducted SUR test of the regression coefficients (V) in Column 1, 3, and 5 in Table 3 and the results are shown in Table 4 (Value 1 and Value 2 in Table 4 are the regression coefficients of the corresponding models). The default assumption is Value 1 is equal to value 2 . Based on Panel A in Table 4, the regression coefficient value (0.21) of AIDptRatio on low education level labor (below bachelor's) amount is significantly larger than 
those of AIDptRatio on high education level labor (Ph.D.) amount (-0.143) and middle education level labor (bachelor's or master's ) amount (-0.24).

That is, the deployment of AI has a stronger positive impact on the demand for low-skill labors than the demand for high-skilled labors. Our finding is consistent with Hypothesis 1. Based on Panel B in Table 4, IT shows positive effects on labor amount across all education levels in the firms. And its effect on low education level labor demand in the firm seems to be the strongest.

As the required education level for a job represents the complexity and difficulty of the part of the job that requires "brain work," our finding indicates that, with the use of AI and IT, this part ("brain work") are essentially "outsourced" to AI or IT, resulting in an effective separation of the "brain work" and the "physical work." As a result, it lowers the required education level for a worker to perform the job, as the worker now only needs to take care of the "physical work" part of the job. Eventually, this leads to the surge of creations of jobs that only deal with the "physical work" to a large degree and corresponding labor demand for low-education level workers in the firms.

Table 2. Correlation Analysis

\begin{tabular}{|c|c|c|c|c|c|c|c|c|c|}
\hline & AIDptRatio & $\ln (I T D p t)$ & ITDptRatio & $\ln ($ Assets $)$ & $\ln ($ BAGrads) & $\ln ($ Age $)$ & FinLev & $\ln ($ Capex $)$ & Returns \\
\hline AIDptRatio & 1.00 & & & & & & & & \\
\hline $\ln (I T D p t)$ & 0.05 & 1.00 & & & & & & & \\
\hline ITDptRatio & 0.27 & 0.10 & 1.00 & & & & & & \\
\hline $\ln$ (Assets) & 0.01 & 0.64 & 0.00 & 1.00 & & & & & \\
\hline $\ln ($ BAGrads) & 0.08 & 0.07 & 0.03 & 0.06 & 1.00 & & & & \\
\hline $\ln ($ Age $)$ & -0.01 & 0.12 & -0.01 & 0.22 & 0.13 & 1.00 & & & \\
\hline FinLev & -0.01 & 0.18 & -0.02 & 0.46 & -0.02 & 0.14 & 1.00 & & \\
\hline $\ln$ (Capex) & 0.01 & 0.55 & 0.01 & 0.60 & 0.08 & -0.01 & 0.14 & 1.00 & \\
\hline Returns & 0.00 & -0.02 & 0.00 & -0.05 & -0.11 & -0.18 & 0.02 & -0.02 & 1.00 \\
\hline
\end{tabular}

Table 3. The Impacts of AI Use and IT Use on Labor

\begin{tabular}{|c|c|c|c|c|c|c|}
\hline & (1) & (2) & (3) & (4) & (5) & (6) \\
\hline & $\ln (P h D)$ & $\ln (P h D)$ & $\ln ($ BMDegrs $)$ & $\ln ($ BMDegrs $)$ & $\ln$ (Others) & $\ln$ (Others) \\
\hline & T0 & $\mathrm{T} 1$ & T0 & $\mathrm{T} 1$ & T0 & $\mathrm{T} 1$ \\
\hline \multirow[t]{2}{*}{ AIDptRatio } & -0.143 & -0.168 & -0.240 & -0.242 & $0.210 * *$ & $0.182 *$ \\
\hline & $(-1.20)$ & $(-1.34)$ & $(-1.54)$ & $(-1.32)$ & $(2.50)$ & $(1.92)$ \\
\hline \multirow[t]{2}{*}{$\ln (I T D p t)$} & $0.058 * *$ & $0.072 *$ & $0.145^{* * * *}$ & $0.137 * * *$ & $0.269 * * *$ & $0.238 * * *$ \\
\hline & $(2.04)$ & (1.94) & $(2.95)$ & $(2.63)$ & $(4.66)$ & $(4.83)$ \\
\hline \multirow[t]{2}{*}{ ITDptRatio } & -0.015 & -0.478 & 0.126 & -0.322 & -0.163 & -0.175 \\
\hline & $(-0.05)$ & $(-1.30)$ & $(0.17)$ & $(-0.42)$ & $(-0.51)$ & $(-0.64)$ \\
\hline \multirow[t]{2}{*}{$\ln ($ BAGrads) } & 0.087 & 0.004 & 0.051 & 0.081 & -0.279 & $-0.393 *$ \\
\hline & $(0.36)$ & $(0.02)$ & $(0.11)$ & $(0.14)$ & $(-1.36)$ & $(-1.68)$ \\
\hline \multirow[t]{2}{*}{$\ln$ (Assets) } & $0.195 * * *$ & $0.188 * * *$ & $0.587 * * *$ & $0.623 * * *$ & $0.356^{* * *}$ & $0.375 * * *$ \\
\hline & $(3.54)$ & $(2.83)$ & $(6.06)$ & $(5.60)$ & $(4.73)$ & $(5.29)$ \\
\hline \multirow[t]{2}{*}{$\ln (A g e)$} & -0.307 & -0.350 & $-1.322 *$ & -1.093 & $0.569 *$ & 0.329 \\
\hline & $(-0.86)$ & $(-0.86)$ & $(-1.94)$ & $(-1.31)$ & (1.84) & $(1.06)$ \\
\hline \multirow[t]{2}{*}{ FinLev } & -0.002 & -0.023 & -0.021 & -0.047 & -0.004 & -0.016 \\
\hline & $(-0.16)$ & $(-1.30)$ & $(-0.80)$ & $(-0.95)$ & $(-0.43)$ & $(-1.08)$ \\
\hline \multirow[t]{2}{*}{$\ln$ (Capex) } & 0.007 & 0.021 & 0.041 & $0.057^{*}$ & $0.045 * * *$ & $0.029 * *$ \\
\hline & $(0.52)$ & $(1.20)$ & (1.34) & (1.89) & $(3.03)$ & $(2.03)$ \\
\hline \multirow[t]{2}{*}{ Returns } & $0.052 * *$ & 0.013 & -0.000 & 0.057 & 0.022 & $0.039 *$ \\
\hline & $(2.14)$ & $(0.55)$ & $(-0.01)$ & $(0.87)$ & $(1.10)$ & $(1.96)$ \\
\hline \multirow[t]{2}{*}{ Cons } & -2.516 & -2.198 & 1.230 & -1.763 & $-10.521 * * *$ & $-7.548 * * *$ \\
\hline & $(-0.80)$ & $(-0.61)$ & $(0.20)$ & $(-0.25)$ & $(-3.90)$ & $(-2.76)$ \\
\hline $\mathrm{N}$ & 4194 & 3449 & 4194 & 3449 & 4194 & 3449 \\
\hline $\mathrm{R}-\mathrm{sq}$ & 0.0703 & 0.0785 & 0.1780 & 0.1884 & 0.3289 & 0.2793 \\
\hline
\end{tabular}

Table 4. Comparisons of the Effects of Al Deployment and IT Deployment on Labor

\begin{tabular}{lllll}
\hline & Value1 & Value2 & Chi2 & P value \\
\hline Panel A: AIDptRatio & & & & \\
\hline PhD VS BMDegrs & -0.143 & -0.240 & 0.55 & 0.459 \\
PhD VS Others & -0.143 & $0.210^{* *}$ & 13.88 & 0.000 \\
BMDegrs VS Others & -0.240 & $0.210^{* *}$ & 10.95 & 0.001 \\
\hline Panel B: ln(ITUse) & & & & \\
\hline PhD VS BMDegrs & $0.058^{* *}$ & $0.145^{* * *}$ & 4.04 & 0.044
\end{tabular}

$\begin{array}{lllll}\text { PhD VS Others } & 0.058 * * & 0.269 * * * & 24.58 & 0.000\end{array}$ $\begin{array}{lllll}\text { BMDegrs VS Others } & 0.145 * * * & 0.269 * * * & 5.42 & 0.020\end{array}$

Figure 1 visualizes the impact of $\mathrm{AI}$ and IT deployment on labor at period $\mathrm{T}$. The horizontal axis shows the different education levels required by the jobs from the lowest to the highest. The vertical axis shows the value of the regression coefficients of AI deployment and IT deployment that indicates the impact of AI or IT deployment on the labor demand at various 
education levels. The blue curve shows the impact of the IT deployment and the orange curve shows the impact of AI deployment. A solid point means the impact is statically significant from zero $(\mathrm{p}<0.1$ or less $)$ and the hollow point means the impact is not statistically significant.

The results and the figure suggest a few important findings. First, IT has a positive effect on labor demand for all education levels. This suggests despite the potential negative replacement effects, IT, as a maturing automation technology, has led to the creations of enough new jobs to overcome it for all education levels. The new jobs are results of higher productivity. Second, the figure indicates that the impact of IT on the demands for workers of different education levels follows the declining pattern: the lower the education level, the stronger the impact. The results for $\mathrm{T}+1$ period are consistent, which suggests such trends are not transient. This can be attributed the replacement of human "brain work" by IT. For the tasks requiring lower education level, which is typically routine tasks that can be programmed, IT replaces human "brain work" more effectively than for tasks requiring higher education level. The latter are typically non-routine jobs that require more complex knowledge and sophisticated cognitive or analytic skills. Consequently, IT lowers the level of education required for human labor to complete the rest of the task more effectively and thus stimulates more demand for such low education labors.

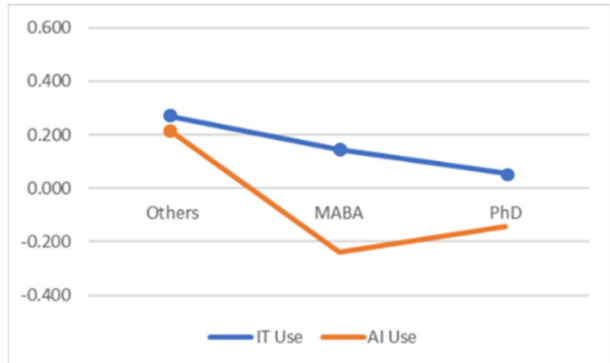

Figure 1. Impact on Labor Structure

Meanwhile, AI shows a significant positive impact only for demand of low education level labor. AI shares much similarity to IT as an automaton technology, which explains their similar positive effects on labor demand for the low-education level through the replacement effect of "brain work". As for jobs requiring middle and high-level educations, AI shows no significant effect. The major differences between IT and AI is AI's ability to perform non-routine cognitive tasks. As such, AI is more capable of replacing human for jobs requiring complex cognitive skills, creativity and decision making than IT. This suggests AI has stronger replacement effect for human labors for jobs requiring higher education levels and consequently a stronger negative effect on demand for labor with higher education level. We also note that $\mathrm{AI}$ is not as mature as
IT in its applications. IT as a mature automation technology has stimulated significant amount of new products, services and businesses and consequently creations of a wide spectrum of jobs requiring different levels of skills and education. The resulted new jobs are more than enough to compensate the jobs loss due to IT's replacing human. AI, on the other hand, is just at its dawn of applications. In fact, so far the most significant commercial applications of AI in terms of scales have focused on the jobs requiring low education levels (e.g. AI customer service agents). AI's applications for tasks requiring middle or high education are yet to reach the depth, width and scale. Consequently, AI are yet to stimulate sufficient new services, products and businesses that lead to new jobs requiring middle or high-level educations as IT. To summarize, on the one hand, AI is more powerful to replace human for jobs requiring middle and high education than IT. On the other hand, AI is currently less effective to stimulate new jobs requiring middle and high education than IT due to less mature applications. These two mechanisms then lead to the overall less positive effects of AI on the demands for workers with middle or high education. However, as AI matures in its applications, we could expect AI to demonstrate a stronger positive effect in stimulating new jobs requiring middle and high education. At that point, the pattern might change.

We next explore whether and how the impact of AI and IT on labor structure of a firm is related to the sector it belongs to. Table 5 demonstrates the summary statistics of AI deployment, IT deployment and counts of employees of the three different education levels at firms in manufacturing and service sectors. The variable "AIDptRatio Raw" is the ratio of AI terms in the firm's annual report before adjusted with the industry average. Based on "AIDptRatio Raw", AI deployment is lower in the manufacturing sector and higher in the service sector.

\begin{tabular}{|c|c|c|c|c|c|}
\hline Variable & Obs & Mean & $\begin{array}{l}\text { Std. } \\
\text { Dev. }\end{array}$ & Min & Max \\
\hline \multicolumn{6}{|c|}{ Manufacturing Sectors - IndMfg } \\
\hline AIDptRatio & 2,862 & 0.02 & 0.26 & -0.22 & 2.29 \\
\hline $\begin{array}{l}\text { AIDptRatio } \\
\text { Raw }\end{array}$ & 2,862 & 0.13 & 0.27 & 0.00 & 2.36 \\
\hline $\ln \left(I T U_{s e}\right)$ & 2,863 & 16.97 & 1.47 & 11.66 & 22.05 \\
\hline $\ln (P h D)$ & 2,863 & 0.38 & 0.94 & 0.00 & 6.46 \\
\hline $\ln (B M D e g r s)$ & 2,863 & 5.39 & 2.03 & 0.00 & 9.85 \\
\hline $\ln$ (Others) & 2,863 & 7.38 & 1.24 & 0.00 & 11.22 \\
\hline \multicolumn{6}{|c|}{ Service Sectors - IndSvc } \\
\hline AIDptRatio & 1,275 & 0.01 & 0.23 & -0.63 & 1.67 \\
\hline $\begin{array}{l}\text { AIDptRatio } \\
\text { Raw }\end{array}$ & 1,275 & 0.16 & 0.30 & 0.00 & 1.94 \\
\hline $\ln \left(I T U_{s e}\right)$ & 1,275 & 17.16 & 1.72 & 10.30 & 22.07 \\
\hline $\ln (P h D)$ & 1,275 & 0.44 & 1.04 & 0.00 & 6.15 \\
\hline
\end{tabular}




$\begin{array}{llllll}\ln (\text { BMDegrs }) & 1,275 & 5.58 & 2.25 & 0.00 & 9.91 \\ \ln \text { (Others) } & 1,275 & 6.72 & 1.67 & 0.00 & 11.19\end{array}$

Table 6 shows the results of the regression model in equation (3). Column 1, 3, and 5 indicate the effect of AI deployment and IT deployment on the count of firm employees of different education levels in period $\mathrm{T}$. Column 2, 4 and 6 indicate these effects in period $\mathrm{T}+1$. Figure 2 shows how AI and IT influence labor demand in manufacturing and service sectors.

For the manufacturing sector, IT deployment has a similar pattern of impact on labor demand for different education levels consistent to that of the full sample analysis: (1) positive effects for all types of labor demands and (2) that the less education required, the stronger the positive effects. However, AI deployment has significant negative impact on demand for labors requiring middle and high-level education in manufacturing sector. The finding suggests that AI has a more powerful replacement effect for human labors for jobs requiring higher educations in manufacturing. In sectors like manufacturing where robotics technology is more suitable and has more mature and wider applications, AI has gained more power in replacing human labors. This result also reminds us that, in order for AI to be more effective to automate the "brain work" part of a job task, application and advancement in robotics that automates the "physical work" part is necessary.

Table 6 The Impact of Al and IT in Manufacturing and Service Sectors

\begin{tabular}{|c|c|c|c|c|c|c|}
\hline & $\begin{array}{l}(1) \\
\ln (P h D) \\
\mathrm{T} 0\end{array}$ & $\begin{array}{l}(2) \\
\ln (P h D) \\
\mathrm{T} 1\end{array}$ & $\begin{array}{l}\text { (3) } \\
\ln (B M D e g r s) \\
\text { T0 }\end{array}$ & $\begin{array}{l}\text { (4) } \\
\ln (\text { BMDegrs) } \\
\mathrm{T} 1\end{array}$ & $\begin{array}{l}\text { (5) } \\
\ln (\text { Others }) \\
\text { T0 }\end{array}$ & $\begin{array}{l}\text { (6) } \\
\ln (\text { Others) } \\
\mathrm{T} 1\end{array}$ \\
\hline AIDptRatio $\times$ IndMfg & $\begin{array}{l}-0.267^{*} \\
(-1.74)\end{array}$ & $\begin{array}{l}-0.227 \\
(-1.40)\end{array}$ & $\begin{array}{l}-0.300 * \\
(-1.81)\end{array}$ & $\begin{array}{l}-0.308 \\
(-1.53)\end{array}$ & $\begin{array}{l}0.107 \\
(1.27)\end{array}$ & $\begin{array}{l}0.193 * \\
(1.91)\end{array}$ \\
\hline AIDptRatio $\times \operatorname{IndSvc}$ & $\begin{array}{l}0.045 \\
(0.23)\end{array}$ & $\begin{array}{l}-0.179 \\
(-0.81)\end{array}$ & $\begin{array}{l}0.161 \\
(0.43)\end{array}$ & $\begin{array}{l}0.297 \\
(0.65)\end{array}$ & $\begin{array}{l}0.515 * * * \\
(2.98)\end{array}$ & $\begin{array}{l}0.353^{*} \\
(1.95)\end{array}$ \\
\hline $\ln (I T D p t) \times \operatorname{IndMfg}$ & $\begin{array}{l}0.087 * * \\
(2.37)\end{array}$ & $\begin{array}{l}0.088^{*} \\
(1.89)\end{array}$ & $\begin{array}{l}0.194 * * * \\
(2.96)\end{array}$ & $\begin{array}{l}0.155^{* *} \\
(2.40)\end{array}$ & $\begin{array}{l}0.284 * * * \\
(4.48)\end{array}$ & $\begin{array}{l}0.225 * * * \\
(4.16)\end{array}$ \\
\hline $\ln (I T D p t) \times \operatorname{IndSvc}$ & $\begin{array}{l}0.011 \\
(0.30)\end{array}$ & $\begin{array}{l}0.040 \\
(1.05)\end{array}$ & $\begin{array}{l}0.089 \\
(1.39)\end{array}$ & $\begin{array}{l}0.116^{*} \\
(1.67)\end{array}$ & $\begin{array}{l}0.252 * * * \\
(3.66)\end{array}$ & $\begin{array}{l}0.268 * * * \\
(4.44)\end{array}$ \\
\hline IndMfg & $\begin{array}{l}-0.805 \\
(-0.49)\end{array}$ & $\begin{array}{l}-2.201 \\
(-1.18)\end{array}$ & $\begin{array}{l}-19.427 * * \\
(-2.03)\end{array}$ & $\begin{array}{l}-19.686^{* *} \\
(-2.36)\end{array}$ & $\begin{array}{l}-4.683 * * * \\
(-3.38)\end{array}$ & $\begin{array}{l}-5.042 * * * \\
(-3.07)\end{array}$ \\
\hline $\operatorname{IndSvc}$ & $\begin{array}{l}0.222 \\
(0.14)\end{array}$ & $\begin{array}{l}-1.676 \\
(-0.90)\end{array}$ & $\begin{array}{l}-17.148^{*} \\
(-1.79)\end{array}$ & $\begin{array}{l}-18.513^{* *} \\
(-2.22)\end{array}$ & $\begin{array}{l}-4.044 * * * \\
(-2.66)\end{array}$ & $\begin{array}{l}-5.460 * * * \\
(-3.19)\end{array}$ \\
\hline ITDptRatio & $\begin{array}{l}-0.203 \\
(-0.67)\end{array}$ & $\begin{array}{l}-0.705^{*} \\
(-1.94)\end{array}$ & $\begin{array}{l}0.474 \\
(0.60)\end{array}$ & $\begin{array}{l}0.046 \\
(0.05)\end{array}$ & $\begin{array}{l}-0.101 \\
(-0.30)\end{array}$ & $\begin{array}{l}0.062 \\
(0.23)\end{array}$ \\
\hline $\ln$ (BAGrads) & $\begin{array}{l}0.084 \\
(0.35)\end{array}$ & $\begin{array}{l}0.010 \\
(0.04)\end{array}$ & $\begin{array}{l}-0.044 \\
(-0.10)\end{array}$ & $\begin{array}{l}-0.023 \\
(-0.04)\end{array}$ & $\begin{array}{l}-0.311 \\
(-1.52)\end{array}$ & $\begin{array}{l}-0.427 * \\
(-1.83)\end{array}$ \\
\hline $\ln$ (Assets) & $\begin{array}{l}0.202 * * * \\
(3.60)\end{array}$ & $\begin{array}{l}0.191 * * * \\
(2.84)\end{array}$ & $\begin{array}{l}0.578 * * * \\
(5.94)\end{array}$ & $\begin{array}{l}0.621 * * * \\
(5.51)\end{array}$ & $\begin{array}{l}0.357 * * * \\
(4.72)\end{array}$ & $\begin{array}{l}0.375 * * * \\
(5.32)\end{array}$ \\
\hline $\ln ($ Age $)$ & $\begin{array}{l}-0.361 \\
(-1.01)\end{array}$ & $\begin{array}{l}-0.376 \\
(-0.91)\end{array}$ & $\begin{array}{l}-1.118^{*} \\
(-1.79)\end{array}$ & $\begin{array}{l}-0.784 \\
(-1.02)\end{array}$ & $\begin{array}{l}0.612 * * \\
(1.97)\end{array}$ & $\begin{array}{l}0.451 \\
(1.47)\end{array}$ \\
\hline FinLev & $\begin{array}{l}-0.001 \\
(-0.08)\end{array}$ & $\begin{array}{l}-0.024 \\
(-1.39)\end{array}$ & $\begin{array}{l}-0.018 \\
(-0.69)\end{array}$ & $\begin{array}{l}-0.044 \\
(-0.89)\end{array}$ & $\begin{array}{l}-0.003 \\
(-0.31)\end{array}$ & $\begin{array}{l}-0.015 \\
(-1.02)\end{array}$ \\
\hline $\ln$ (Capex) & $\begin{array}{l}0.007 \\
(0.50)\end{array}$ & $\begin{array}{l}0.021 \\
(1.24)\end{array}$ & $\begin{array}{l}0.040 \\
(1.31)\end{array}$ & $\begin{array}{l}0.055^{*} \\
(1.83)\end{array}$ & $\begin{array}{l}0.044 * * * \\
(2.94)\end{array}$ & $\begin{array}{l}0.027^{*} \\
(1.88)\end{array}$ \\
\hline Returns & $\begin{array}{l}0.053^{* *} \\
(2.20)\end{array}$ & $\begin{array}{l}0.013 \\
(0.58)\end{array}$ & $\begin{array}{l}0.010 \\
(0.17)\end{array}$ & $\begin{array}{l}0.070 \\
(1.07)\end{array}$ & $\begin{array}{l}0.025 \\
(1.23)\end{array}$ & $\begin{array}{l}0.041^{* *} \\
(2.07)\end{array}$ \\
\hline Cons & $\begin{array}{l}-1.779 \\
(-0.59)\end{array}$ & $\begin{array}{l}-0.041 \\
(-0.01)\end{array}$ & $\begin{array}{l}18.343 \\
(1.58)\end{array}$ & $\begin{array}{l}15.102 \\
(1.37)\end{array}$ & $\begin{array}{l}-6.412 * * \\
(-2.36)\end{array}$ & $\begin{array}{l}-3.329 \\
(-1.18)\end{array}$ \\
\hline $\mathrm{N}$ & 4194 & 3449 & 4194 & 3449 & 4194 & 3449 \\
\hline R-sq & 0.0752 & 0.0832 & 0.1857 & 0.1966 & 0.3340 & 0.2887 \\
\hline
\end{tabular}
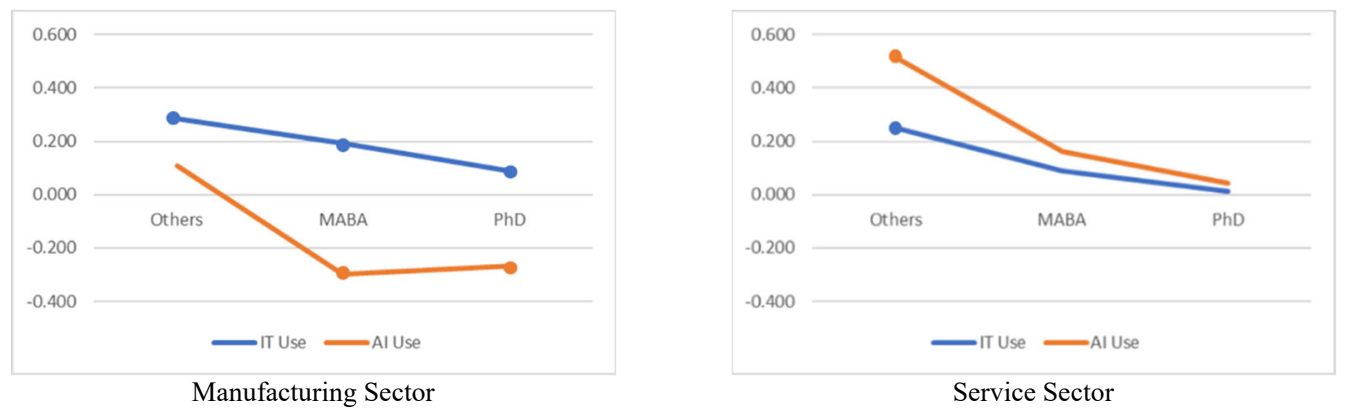

Figure 2. Labor Demand Growth Rate in Manufacturing and Service Sectors 
In the service sector, both AI deployment and IT deployment have positive effects only for jobs requiring low education while their effects on jobs requiring middle or high-level education are not statistically significant. This finding suggests that, for service sector where non-routine jobs are typically an integral part of the service and the middle and high level jobs often require inter-person communication and cognitive skills (e.g. education and health care) or creativity, IT has a less prominent roles to play despite its mature applications. Also, if we compare the effects of AI or IT in manufacturing and service sectors, AI has a stronger impact in the service sector than in the manufacturing sector while IT has a similar level of impact for both the service and the manufacturing sectors. Our finding is consistent with Hypothesis 2, which notes that AI is especially powerful for non-routine jobs involving personalization and customization, which makes AI especially influential in the service sector than in the manufacturing sectors. where jobs are more likely to involve routine tasks.

\section{Summary and Discussion}

Since the inception of industrialization, a major concern of the society is whether automation will deprive humans of jobs and reduce the share of human labor in the whole production process of our society. Multiple theories offered competing explanations and predictions on this issue.

Our empirical study reported in this paper lends support to the "technology-enabled deskilling" effect theory - i.e. AI reduces the education level requirement for certain jobs and accordingly it shows a strong positive effect on jobs requires low education levels (below college). As AI is able to replace human for the relatively complex cognitive and analytic tasks, it essentially lowered the job entry requirement. This surprising strong complimentary effect of AI on labor demand for low-skill workers could have far-reaching implications for innovative business models and labor market landscape. Moreover, our study shows this effect is stronger in the service sector than in the manufacturing sector. We attribute this to the fact that in service sector there are more non-routine jobs than in manufacturing sectors. When AI overtakes the part of a non-routine job that requires sophisticated cognitive or analytic skills, it separates the high-skill part of the job to the low-skill part and increase the demand for lowskill workers. It does so more in the service sector than in the manufacturing sector. Finally, the study shows although AI is built on the traditional IT infrastructure, it differs from IT in their effects on labor demand in an organization in notable ways. This is due to their different stages in terms maturity of the technology and their applications and the unprecedented capacity of AI to overtake jobs requesting sophisticates cognitive and analytic skills.

This study has quite some limitations that we hope to explore further in our future research. One of such limitations is our measure of AI deployment, which is the count of AI related terms in the firms' annual reports. We do not observe the actual application of AI in firms. Recent studies on task-technology fit (TTF) and affordance theory finds that AI is better fit for certain tasks than others. As such, a micro level analysis of the application of AI at the task level will be fruitful in better understanding the underlying mechanism of the effect of AI labor demand. The second limitation of this study is the challenge in establishing causality. While we try to establish (Granger) causality by analyzing response variables in the $t+1$ period, the relationships identified are ultimately associations rather than causal effects. There may also exist potential confounders that we did not control.

\section{References}

[1] Agrawal, A., Gans, J. S. and Goldfarb, A. 2019. "Artificial intelligence: the ambiguous labor market impact of automating prediction". Journal of Economic Perspectives, 33(2), 31-50.

[2] Zhou, G., Chu, G., Li, L. and Meng, L. 2020. "The effect of artificial intelligence on China's labor market". China Economic Journal, 13(1), 24-41.

[3] Frank, M. R., et al. 2019. "Toward understanding the impact of artificial intelligence on labor." Proceedings of the National Academy of Sciences 116.14, 6531-6539.

[4] Acemoglu, D. and Restrepo, P. 2020. "The wrong kind of AI? Artificial intelligence and the future of labour demand." Cambridge Journal of Regions, Economy and Society, 13(1), 25-35.

[5] Katz, L. F. and Murphy, K. M. 1992. "Changes in relative wages, 1963-1987: supply and demand factors." The quarterly journal of economics, 107(1), 35-78.

[6] Autor, D. H., Katz, L. F. and Krueger, A. B. 1998. "Computing inequality: have computers changed the labor market?." The Quarterly journal of economics, 113(4), 1169-1213.

[7] Katz, L. F and Autor, D. H. 1999. "Changes in the wage structure and earnings inequality." Handbook of labor economics, Vol. 3, 1463-1555.

[8] Goldin, C. and Katz, L. F. 2010. "The Race between Education and Technology." Harvard University Press.

[9] Bresnahan, T. F., Brynjolfsson, E. and Hitt, L. M. 2002. "Information technology, workplace organization, and the demand for skilled labor: Firm-level evidence." The quarterly journal of economics, 117(1), 339-376.

[10] Autor, D. H., Katz, L. F. and Kearney, M. S. 2006. "The polarization of the US labor market." American economic review, 96(2), 189-194. 
[11] Goos, M. and Manning, A. 2007. "Lousy and lovely jobs: The rising polarization of work in Britain." The review of economics and statistics, 89(1), 118-133.

[12] Goos, M., Manning, A. and Salomons, A. 2009. "Job polarization in Europe." American economic review, 99(2), 58-63.

[13] Autor, D. H., Levy, F. and Murnane, R. J. 2003. "The skill content of recent technological change: An empirical exploration." The Quarterly journal of economics, 118(4), 1279-1333.

[14] Acemoglu, D. and Autor, D. H. 2012. "What does human capital do? A review of Goldin and Katz's the race between education and technology." Journal of Economic Literature, 50(2), 426-63.

[15] Autor, D. H. 2013. "The "task approach" to labor markets: an overview." Journal for Labour Market Research, 46(3), 185-199.

[16] Mishel, L., Shierholz, H. and Schmitt, J. 2013. "Don't blame the robots. " Assessing the Job Polarization Explanation of Growing Wage Inequality, EPI-CEPR working paper.

[17] Autor, D. H. 2015. "Why are there still so many jobs? The history and future of workplace automation." Journal of economic perspectives, 29(3), 3-30.

[18] Autor, D. H. 2010. "The Polarization of Job Opportunities in the U.S. Labor Market, Implications for Employment and Earnings." Center for American Progress and Brookings Institution: The Hamilton Project.

[19] Acemoglu, D. and Autor, D. H. 2011. "Skill, T asks and Technologies: Implications for Employment Earnings." In O.Ashenfelter and D. Card (eds.), The Handbook of Labor Economics, vol. 4b. Amsterdam: Elsevier.

[20] Lyons, J. S. 1978. "The Lancashire Cotton Industry and the Introduction of the Powerloom, 1815-1850." The Journal of Economic History, 38(1), 283-284.

[21] Chin, A., Juhn, C. and Thompson, P. 2006. "Technical change and the demand for skills during the second industrial revolution: evidence from the merchant marine, 1891-1912." The Review of Economics and Statistics, 88(3), 572-578.

[22] Van Horn, C. E. and Schaffner, H. A. (Eds.). 2003. "Work in America: MZ." Abc-clio.

[23] Mittal, N. and Nault, B. R. 2009. "Research noteInvestments in information technology: Indirect effects and information technology intensity". Information systems research, 20(1), 140-154.

[24] Tambe, P., 2014. "Big data investment, skills, and firm value." Management Science, 60(6), 1452-1469.

[25] Li, J., Li, M., Wang, X. and Thatcher, J. B. 2021 "Strategic Directions for AI: The Role of CIOs and Boards of Directors". MIS Quarterly, 45(3), 1603-1643.

[26] Mikolov, T., Chen, K., Corrado, G. and Dean, J. 2013. "Efficient estimation of word representations in vector space." arXiv preprint arXiv, 1301.3781.

[27] Le, Q. and Mikolov, T. 2014. "Distributed representations of sentences and documents." In International conference on machine learning, 11881196.

[28] Song, Y., Shi, S., Li, J. and Zhang, H. 2018. "Directional skip-gram: Explicitly distinguishing left and right context for word embeddings." Proceedings of the 2018 Conference of the North American Chapter of the Association for Computational Linguistics: Human Language Technologies, Volume 2 (Short Papers), 175180.

[29] Dixon, J., Hong, B. and Wu, L. 2020. "The Robot Revolution: Managerial and Employment Consequences for Firms." NYU Stern School of Business.

[30] Brynjolfsson, E. and Mitchell, T. 2017. "What Can Machine Learning Do? Workforce Implications." Science, 358(6370), 1530-1534

[31] Brynjolfsson, Ek, Mitchell, T. and Rock, D. 2018. "What Can Machines Learn, and What Does It Mean for Occupations and the Economy?" AEA Papers and Proceedings, 108: 43-47.

\section{Appendix}

\section{Appendix Table 1. Dictionary of Al terms}

\begin{tabular}{ll}
\hline AI terms in Chinese & AI terms in English \\
\hline 人工智能 & Artificial Intelligence \\
AI & AI \\
AI+ & AI+ \\
AI+医疗 & AI+ Medical Care \\
AI 技术 & AI Technology \\
AI 领域 & AI Field \\
AI 工工智能 & Artificial Intelligence \\
AI 时代 & AI Age \\
AI 芯片 & AI Chip \\
大数据 & Big Data \\
大数据和云计算 & Big Data and Cloud Computing \\
大数据与人工智能 & Big Data and Artificial Intelligence \\
发展人工智能 & Developing artificial intelligence \\
机器人和人工智能 & Robot and Artificial Intelligence \\
机器人技术 & Robotics \\
机器学习 & Machine Learning \\
机器智能 & Machine Intelligence \\
计算机视觉 & Computer Vision \\
人工智能 AI & Artificial Intelligence \\
人工智能产业 & Artificial Intelligence Industry \\
人工智能的发展 & Development of Artificial Intelligence \\
人工智能的未来 & The future of Artificial Intelligence \\
人工智能和机器学习 & Artificial Intelligence and Machine \\
人工智能化 & Learning \\
人工智能机器 & Artificial Intelligence \\
人工智能机器人 & Artificial Intelligence Machine \\
人工智能技术 & Artificial Intelligence Robot \\
人工智能领域 & Artificial Intelligence Technology \\
人工智能深度学习 & Artificial Intelligence Field \\
人工智能时代 & Artificial Intelligence and Deep \\
& Artificial Intelligence Age \\
\hline
\end{tabular}




\begin{tabular}{ll} 
人工智能算法 & Artificial Intelligence Algorithm \\
人工智能芯片 & Artificial Intelligence Chip \\
人工智能研发 & Research and Development of Artificial \\
人工智能应用 & Intelligence \\
认知计算 & Artificial Intelligence Application \\
认知技术 & Cognitive Computation \\
深度学习 & Cognitive Technology \\
深度学习算法 & Deep Learning \\
图像识别 & Deep Learning Algorithm \\
物联网 & Pattern Recognition \\
新兴科技 & Internet of Things \\
云计算 & Emerging Technology \\
智能 & Cloud Computing \\
智能机器 & Intelligence \\
智能技术 & Intelligent Machine \\
\hline
\end{tabular}

\section{Appendix Table 2. Dictionary of IT terms}

\begin{tabular}{|c|c|}
\hline IT terms in Chinese & IT terms in English \\
\hline 信息系统 & Information System \\
\hline 服务系统 & Service System \\
\hline 管理平台 & Management Platform \\
\hline 管理系统 & Management System \\
\hline 管理信息系统 & Management Information System \\
\hline 平台系统 & Platform System \\
\hline 企业信息系统 & Enterprise Information System \\
\hline 软件系统 & Software System \\
\hline 实现信息 & Realization of information \\
\hline 数据共享 & Data Sharing \\
\hline 数据互联互通 & Interconnection in Data \\
\hline 数据集成 & Data Integration \\
\hline 数据系统 & Data System \\
\hline 数据信息 & Data Information \\
\hline 统一平台 & Integrated Platform \\
\hline 网络系统 & Network System \\
\hline 网络信息系统 & Network Information System \\
\hline 系统平台 & System Platform \\
\hline 系统数据 & System Data \\
\hline 相关系统 & Related System \\
\hline 信息管理 & Information Management \\
\hline 信息管理平台 & Information Management Platform \\
\hline 信息管理系统 & Information Management System \\
\hline 信息互联互通 & Interconnection in Information \\
\hline 信息化管理 & Informatization Management \\
\hline 信息化管理系统 & Informatization Management System \\
\hline 信息化平台 & Informatization Platform \\
\hline 信息化系统 & Informatization System \\
\hline
\end{tabular}

$\begin{array}{ll}\text { 信息数据 } & \text { Information Data } \\ \text { 信息网络系统 } & \text { Information Network System } \\ \text { 信息系统建设 } & \text { Information System Construction } \\ \text { 信息系统平台 } & \text { Information System Platform } \\ \text { 业务管理系统 } & \text { Operation Management System } \\ \text { 业务系统 } & \text { Operation System } \\ \text { 业务信息系统 } & \text { Operating Information System } \\ \text { 业务应用系统 } & \text { Business Application System } \\ \text { 应用系统 } & \text { Application System } \\ \text { 云平台 } & \text { Cloud Platform }\end{array}$

综合管理系统 Comprehensive Management System

综合信息系统 Integrated Information System

Appendix Table 3. Description of Key Measures and Data Sources

\begin{tabular}{|c|c|}
\hline Measure & escription \\
\hline \multicolumn{2}{|l|}{ Labor Structure } \\
\hline $\ln (P h D)$ & $\begin{array}{l}\text { Number of employees with doctor degree and in } \\
\text { natural logarithm. }\end{array}$ \\
\hline $\ln (B M D e g r s)$ & $\begin{array}{l}\text { Number of employees with bachelor's and } \\
\text { master's as the highest degree in natural logarithm. }\end{array}$ \\
\hline $\ln$ (Others) & $\begin{array}{l}\text { Number of employees whose highest education is } \\
\text { high school, vacation school or lower in natural } \\
\text { logarithm. }\end{array}$ \\
\hline \multicolumn{2}{|c|}{ AI Deployment \& IT Deployment } \\
\hline AIDptRatio & $\begin{array}{l}\text { AI deployment proxy: the ratio of AI related terms } \\
\text { in the firm's annual report adjusted with industry } \\
\text { average. }\end{array}$ \\
\hline $\begin{array}{l}\text { AIDptRatio } \\
\text { Raw }\end{array}$ & $\begin{array}{l}\text { The ratio of AI terms in the firm's annual report } \\
\text { before adjusted with the industry average. }\end{array}$ \\
\hline $\ln (I T D p t)$ & $\begin{array}{l}\text { IT deployment proxy, using the firm's IT related } \\
\text { fixed assets, including electronic equipment and } \\
\text { computers and auxiliary equipment, in natural } \\
\text { logarithm. }\end{array}$ \\
\hline \multicolumn{2}{|c|}{ Control Variables } \\
\hline ITDptRatio & $\begin{array}{l}\text { lated terms } \\
\text { th industry }\end{array}$ \\
\hline $\ln ($ BAGrads) & $\begin{array}{l}\text { Number of undergraduate graduates in each } \\
\text { province }(x 10,000) \text { in natural logarithm. }\end{array}$ \\
\hline $\ln (A$ & Total assets in natural logarithm. \\
\hline $\ln ($ Age $)$ & The age of listed firms (days) in natu \\
\hline FinLev & $\begin{array}{l}\text { Financial Leverage, using equity multiplier as a } \\
\text { proxy indicator, calculated by dividing the ending } \\
\text { balance of total assets by the ending balance of } \\
\text { owner's equity. }\end{array}$ \\
\hline $\ln ($ Capex $)$ & $\begin{array}{l}\text { Capital expenditures: cash paid for the purchase } \\
\text { and construction of fixed assets, intangible assets } \\
\text { and other long-term assets in a year. }\end{array}$ \\
\hline Returns & The annual returns of individual stocks adjusted \\
\hline \multicolumn{2}{|c|}{ Sector Structure } \\
\hline IndMfg & The \\
\hline IndSvc & The tl \\
\hline
\end{tabular}

